\title{
Characteristics of emotion regulation among adults with chronic stuttering
}

\section{Cechy kontroli emocjonalnej osób dorosłych z chronicznym jąkaniem}

\author{
Department of Pathology and Rehabilitation of Speech, Medical University of Lublin, Lublin, Poland \\ Correspondence: Dr hab. Ewa Humeniuk, Department of Pathology and Rehabilitation of Speech, Medical University of Lublin, Staszica 4/6, 20-081 Lublin, Poland, \\ tel.: +48502379 040, e-mail: ewahumeniuk@umlub.pl \\ Dr hab. Ewa Humeniuk, Zakład Patologii i Rehabilitacii Mowy, Uniwersytet Medyczny w Lublinie, ul. Staszica 4/6, 20-081 Lublin, Poland, tel.: +48502 379 040, e-mail: ewahumeniuk@umlub.pl
}

\begin{abstract}
The aim of the study: The aim of the thesis was to determine the characteristics of emotion regulation among adults with chronic stuttering. A hypothesis was proposed that such individuals demonstrate certain characteristic features within the area of emotion regulation distinguishing them from people who speak fluently. Material and methods: The study involved the participation of volunteers. The group consisted of 68 adults with chronic stuttering. The control group (62) consisted of non-stuttering individuals, selected for the research group in reference to gender and age. The Emotion Regulation Questionnaire developed by J. Brzeziński was used to measure the characteristics of emotion regulation. The questionnaire consists of the following scales: situation control scale, emotional arousal scale, emotional and rational motivation scale, emotional resilience scale, expressivity control scale. The obtained profile gives the emotion regulation structure. Results: A different profile of emotion regulation was identified among the stuttering individuals than among the control group. Stuttering individuals show more excitement in emotionally arousing situations, are less emotionally resilient and control their expressiveness to a lower extent. They also demonstrate a greater ability to control emotogenic situations. The model of monitoring one's own behaviour is similar within these two groups. Conclusions: The characteristics of emotion regulation among adults with chronic stuttering may cause their behaviour to become disorganised to a greater extent under the influence of emotions.
\end{abstract}

Keywords: stuttering, chronic stuttering, adults, emotion regulation

Streszczenie Cel pracy: Celem pracy było określenie cech kontroli emocjonalnej u osób dorosłych z chronicznym jąkaniem. Postawiono hipotezę, że osoby te posiadają specyficzne cechy w zakresie kontroli emocjonalnej różniące je od ludzi mówiących płynnie. Materiał i metody: W badaniach uczestniczyli ochotnicy. Grupę badaną stanowiło 68 osób dorosłych z chronicznym jąkaniem. Grupa kontrolna (62) składała się z osób niejąkających się, które zostały dobrane do grupy badanej pod względem płci i wieku. Do pomiaru właściwości kontroli emocjonalnej zastosowano Kwestionariusz Kontroli Emocjonalnej J. Brzezińskiego, składający się z następujących skal: kontroli sytuacji, pobudliwości emocjonalnej, motywacji emocjonalno-racjonalnej, odporności emocjonalnej, kontroli ekspresji. Uzyskany profil obrazuje strukturę kontroli emocjonalnej. Wyniki: U osób jąkających się stwierdzono odmienny profil kontroli emocjonalnej niż w grupie kontrolnej. Osoby jąkające się są bardziej pobudliwe emocjonalnie, przy jednoczesnym mniejszym stopniu odporności emocjonalnej i mniejszym stopniu kontroli ekspresji. Wykazują się też wyższym poziomem zdolności do kontrolowania sytuacji emotogennych. Typ sterowania własnym zachowaniem jest podobny w obydwu grupach. Wnioski: Cechy kontroli emocjonalnej osób dorosłych z chronicznym jąkaniem mogą sprawiać, że ich zachowanie w większym stopniu będzie ulegało dezorganizacji pod wpływem emocji.

Słowa kluczowe: jąkanie, jąkanie chroniczne, dorośli, kontrola emocjonalna 


\section{INTRODUCTION}

$\mathrm{T}$ The concept of regulation refers to processes present in the modification of emotional reactions and self-managing processes, whose aim is to achieve changes within the areas of: intensity, temporal features, types of expressiveness and functioning, content or types of experienced emotions, consequences of emotional processes (Górska and Soroko, 2004; Gross and John, 1995; Pastuszak-Draxler et al., 2016). The fundamental assumption of such definition of regulation is that everyone experiences emotions and that there is an optimal level of experiencing and expressing them.

Emotion regulation can be understood as: a relatively constant personality trait (Doliński, 2000a), behaviour (Gross and Thompson, 2007; Posner and Rothbart, 2000); techniques (Doliński, 2000b; Rottenberg and Gross, 2003); a process involving the initiation of an emotional state, its stabilisation, monitoring, assessment or modification (Eisenberg et al., 2000; Krohne et al., 2002). Within the processual approach, emotion regulation fully explains its course and effectiveness, or the lack of it (Gross, 2002).

The first stage of emotional process control is related to conscious avoidance or search of situations and events which, to the person's knowledge, inspire them with emotions of different types. If these situations take place, the regulation may be connected with appropriate cognitive actions, which either select or modify the pieces of coming information. Among the types of regulation, there are an appropriately oriented cognitive apparatus and diversion of attention or strong concentration on the important aspects of emotogenic situations (Gross and John, 2003; Worthman, 2009). An individual performs cognitive operations associated with information, frequently in the form of interpreting it in order to change its meaning, and the defence mechanisms are the best examples here. If we consider cognitive assessment as one of the types of emotion regulation, it has to be stressed that people differ in their awareness of the emotions they experience. Becoming aware of the emotions one experiences enables to give them full meaning. It was determined that the awareness of the level of physiological arousal may be important for the course of regulation processes (Critchley, 2009; Kayser et al., 2009; Pollatos et al., 2007).

The next stage of emotion regulation are processes connected with the way in which emotional states are expressed and behaviour control. They can be related to an individual excluding the expression of the emotions experienced, but also to blocking the activation of processes connected with the experienced emotions (Doliński, 2000a).

Successful emotion regulation includes a set of skills, such as planning, monitoring and assessment. From this point of view, distinct similarities between emotion regulation processes and the control of speech fluency can be observed. In order for a person to speak fluently, he needs to be able to take control of his speech, to monitor it in the course of action and to avoid mistakes or correct them (Shimamura, 2000; Troyer et al., 1997). Furthermore, communication processes are connected with the emergence of various emotions. The ability to control them while speaking influences speech fluency (Gyurak et al., 2009). According to Feldner et al. (2003), research on emotion regulation should be carried out in various clinical populations. The identification of the incorrect emotion regulation strategies usage may indicate the risk factors in the development of a given disorder.

As far as research on emotion regulation among adults who stutter is concerned, there are no studies devoted to it, although it is commonly emphasised that the ability to cope with emotions may be a variable having a significant impact on speech fluency. It is common knowledge that stuttering people take a number of actions in order to avoid speaking in certain situations or to hide their speech disfluency. However, they should be defined as strategies of dealing with stuttering itself, rather than with emotions (Tarkowski, 2018).

The aim of the study was to determine the characteristics of emotion regulation among adults with chronic stuttering. A hypothesis was proposed that such individuals demonstrate certain characteristic features within the area of emotion regulation distinguishing them from people who speak fluently.

\section{MATERIAL AND METHODS}

Volunteers took part in the study. The group of stuttering individuals (68) was recruited owing to the assistance of the Nationwide Association for People who Stutter. The control group (62) consisted of non-stuttering individuals, who were selected for the research group in reference to gender and age. The characteristics of respondents are presented in Tab. 1.

On average, the stuttering individuals (27.18) were 2 years older than the respondents in the control group (24.90).

The basic criteria for the selection of the stuttering individuals were age above 18 years old, experienced developmental stuttering and its durability. All respondents started to stutter in early childhood. The average age for the beginning of stuttering among the women was 4.25 , and among

\begin{tabular}{|c|c|c|c|c|c|}
\hline \multicolumn{2}{|c|}{ Variables } & \multicolumn{2}{c|}{ Stuttering } & \multicolumn{2}{c|}{ Non-stuttering } \\
\cline { 3 - 6 } & $n$ & $\%$ & $n$ & $\%$ \\
\hline \multirow{2}{*}{ Gender } & Female & 24 & 35.29 & 18 & 29.04 \\
\cline { 2 - 6 } & Male & 44 & 64.71 & 44 & 70.96 \\
\hline \multirow{2}{|c|}{ Average age } & $27.18(S D=8.33)$ & $24.90(S D=4.12)$ \\
\hline \multirow{2}{*}{$\begin{array}{c}\text { Place } \\
\text { of residence }\end{array}$} & Town & 52 & 77.94 & 38 & 61.29 \\
\cline { 2 - 6 } & Countryside & 15 & 22.06 & 24 & 38.71 \\
\hline \multirow{2}{*}{\begin{tabular}{c} 
Education level \\
\cline { 2 - 6 }
\end{tabular}} & Basic & 4 & 5.88 & 3 & 4.84 \\
\cline { 2 - 6 } & Secondary & 37 & 54.41 & 59 & 95.16 \\
\cline { 2 - 6 } & Higher & 27 & 39.71 & 0 & 0.00 \\
\hline
\end{tabular}

Tab. 1. Characteristics of respondents 
the men 4.36 years old. The average age for the beginning of stuttering for the whole group was 4.32 years old.

Emotion Regulation Questionnaire developed by J. Brzeziński was used to measure the characteristics of emotion regulation taking place at the subsequent stages of the duration of emotional processes (scales: situation control, emotional arousal, emotional and rational motivation, emotional resilience, expressivity control) (Brzeziński, 1973, 1980).

The Questionnaire is composed of 45 statements. The raw results are converted into standard ten $(\mathrm{T})$. The results below $30 \mathrm{~T}$ are treated as significantly below normal - difficulties with inhibition of emotional experiences and high emotional reactivity. The average results ranging from 50-70T, are interpreted as the correct emotion regulation. The results above $70 \mathrm{~T}$ are considered to be high, and they signify the inhibition of emotional expression (emotional rigidity). The psychometric profile obtained presents the structure of emotion regulation.

The study was conducted in compliance with the effective principles of the Declaration of Helsinki. The participants were informed about the aim of the study and agreed in a written form to take part in it. The approval of the Bioethics Committee of the Medical University of Lublin was obtained in order to carry out the study (KE-0254/222/210).

Statistical analysis was carried out with the usage of Calculate Sheet in Excel 2016, relying on the Student's $t$-test procedure, chosen after evaluating the shape of the layout of the analysed data. In the study, a margin for the degree and type of error was accepted, based on the rejection of the null hypothesis assuming lack of statistically significant differences and equalling 0.05 . The basic hypothesis was verified by means of two-sided level of significance.

\section{RESULTS}

A different emotion regulation profile was determined among the stuttering individuals than within the control group (Tab. 2). The stuttering individuals are more emotionally aroused $(p<0.02)$, while being less emotionally resilient $(p<0.05)$ and showing less expressivity control $(p<0.05)$. People who stutter, although the difference is not statistically significant, demonstrate the ability to control emotogenic situations by their appropriate perception and

\begin{tabular}{|l|c|c|c|c|c|}
\hline $\begin{array}{l}\text { Scales } \\
\text { of Emotion Regulation } \\
\text { Questionnaire }\end{array}$ & \multicolumn{2}{|c|}{ Stuttering } & \multicolumn{2}{|c|}{$\begin{array}{c}\text { Non- } \\
\text { stuttering }\end{array}$} & \multirow{2}{*}{$\boldsymbol{t}(\boldsymbol{p})$} \\
\cline { 2 - 5 } & $\boldsymbol{M}$ & SD & $\boldsymbol{M}$ & SD & \\
\hline Situation control scale & 51.53 & 10.20 & 48.57 & 7.38 & $1.88(\mathrm{NS})$ \\
\hline Emotional arousal scale & 57.54 & 6.28 & 53.86 & 6.83 & $3.20(<0.01)$ \\
\hline $\begin{array}{l}\text { Emotional and rational } \\
\text { motivation scale }\end{array}$ & 54.03 & 8.31 & 53.62 & 6.51 & $0.31(\mathrm{NS})$ \\
\hline Emotional resilience scale & 54.91 & 8.02 & 58.19 & 6.52 & $2.54(<0.01)$ \\
\hline Expressivity control scale & 39.59 & 8.70 & 43.69 & 11.03 & $2.36(<0.02)$ \\
\hline
\end{tabular}

Tab. 2. Averages and differences between them achieved by test groups in Emotion Regulation Questionnaire

\begin{tabular}{|c|c|c|}
\hline $\begin{array}{c}\text { Scales of Emotion Regulation } \\
\text { Questionnaire }\end{array}$ & Stuttering & $\begin{array}{c}\text { Non- } \\
\text { stuttering }\end{array}$ \\
\hline Situation control scale & Average & Average \\
\hline Emotional arousal scale & Average & Average \\
\hline Emotional and rational motivation scale & Average & Average \\
\hline Emotional resilience scale & Average & Average \\
\hline Expressivity control scale & Low & Average \\
\hline
\end{tabular}

Tab. 3. Psychosometric interpretation of results achieved by tests groups in Emotion Regulation Questionnaire

interpretation. The type of one's own behaviour control is similar in both groups (Tab. 3 ).

The average result of the situation control scale means that the stuttering people do not come rashly into emotogenic situations, and they do not excessively avoid them. However, when emotional stimuli emerge, they easily develop a certain emotional state, which is due to the fact that they are characterised by a higher level of general emotional arousal. It is more difficult for them to stifle the progressing process, and their behaviour can undergo a greater extent of disorganisation due to the experienced emotions. These individuals are less resilient and they are able to control their behaviour to a lesser degree. It manifests itself in the difficulties to hide the external symptoms of the experienced emotional states, such as e.g. body movements, shaking hands, mimic facial expression, laughter, crying, vocalisation. The general overview of the results obtained on emotion regulation allows to acknowledge that people who stutter are characterised by a lower ability to regulate emotions, and by a greater tendency for impulsive types of behaviour in situations when emotions are experienced.

\section{DISCUSSION}

Rottenberg and Gross (2003) define the emotion regulation as processes responsible for monitoring, evaluating and modifying emotional reactions, especially their intensive and temporal features. People, who are not able to control their emotions, develop a disregulated type of behaviour. Whereas, effective emotion regulation results in the appropriate course of cognitive, motor and physiological processes, enabling them to maintain the previous direction and efficiency of actions (Banfield et al., 2004).

It was assumed in this paper that emotion regulation is a process ranging from becoming to not becoming involved in emotogenic situations through developing emotional activation influencing the direction and efficiency of action and expression of emotions. It was assumed that emotion regulation characteristics are among the causes of the development and maintenance of stuttering. Research on this issue among children was initiated by Karrass et al. (2006). They assumed and confirmed in their study that the current speech fluency is conditioned by a child's skills, situational requirements and by permanent features such as reactivity and emotion regulation. 
The authors came to the conclusion that, if high-reactive children stutter, it means that they focus on their disfluency too much, paying excessive attention to the mistakes they make while speaking which triggers negative emotions they are not able to deal with. All this results in the prolongation and maintenance of disfluency. Children with opposite features pay no attention to their disfluency and selfhealing is more frequent in their case. Other study showed that speech fluency is an important measure of the efficiency of emotion regulation. Higher level of speech fluency was associated with more effective emotion regulation (Gyurak et al., 2009). Due to the fact that the results indicate the connection between speech fluency and emotion regulation, an attempt was made to determine the emotion regulation characteristics among adults with chronic stuttering. The results of the study conducted confirmed the hypothesis that stuttering adults are characterised by a different profile of emotion regulation than people speaking fluently. It was determined that they do not come into emotogenic situations (new, conflicts, threatening) too easily, neither do they excessively avoid them (e.g. by means of defence-oriented perception or interpretation). They exert more control in these types of situations compared to people speaking fluently, but the difference was not statistically significant. However, a statistically significant greater control of a situation was observed in the group of people affected by rheumatoid arthritis (Basińska, 2006) psoriasis (Orzechowska et al., 2009).

The next stage of emotion regulation is the ease with which a person comes under an emotional state influenced by the existing situation. The easier the emotional states emerge, the greater the emotional arousal (reactivity) (Fedeli, 2004). Such characteristic feature was found within a group of stuttering adults. They become more emotionally aroused than people who speak fluently. They are more emotionally aroused than other clinical groups, such as people affected by psoriasis (Orzechowska et al., 2009), or rheumatoid arthritis (Basińska, 2006). At this point, a significant relationship has to be noted. The above mentioned clinical groups were characterised by a greater control on the level of situational perception and lower emotional arousal. These features of emotion regulation within a group of people affected by psoriasis correlated positively with rare usage of less favourable strategies of stress management (Orzechowska et al., 2009). A group of people who stutter is characterised by a lesser control at the level of situational perception, but by a higher level of emotional arousal.

The third stage of emotion regulation are processes connected with behaviour control while experiencing emotions. The respondents who stutter are less emotionally resilient than people who speak fluently, which leads to a conclusion that they are less able to control their behaviour, therefore becoming disorganised more often. Due to the fact that, in stuttering people, the disarraying impact of emotions is revealed while speaking, according to Karrass aimed at improving their operational efficiency. As it was remarked by Vanryckeghem et al. (2004) these strategies are used very often and may influence, to some extent, the level of emotional arousal and improve operational efficiency. As our own studies have shown, stuttering people have a lower ability to control the expressivity of experienced emotions. The authors of the study point to the fact that inhibition of expressivity can cause increase in physiological arousal, which may, in consequence, have a disarraying impact on their behaviour (Cacioppo et al., 1992).

\section{CONCLUSIONS}

1. A different profile of emotion regulation was identified among the stuttering individuals than among the control group.

2. The stuttering individuals demonstrate a greater ability to control emotogenic situations by their appropriate perception and interpretation.

3. In comparison with people speaking fluently, the stuttering individuals are characterised by a higher level of general emotional arousal and lower level of expressivity control.

4. Lower level of resilience in stuttering people may lead to their behaviour becoming disorganised to a greater extent under the influence of emotions.

\section{Conflict of interest}

The authors do not report any financial or personal relationships with other individuals or organisations, which could have a negative influence on the content of the publication and claim rights to this publication.

\section{Funding/Support and role of the sponsor}

DS 509 - Medical Univeristy of Lublin. 


\section{References}

Banfield JF, Wyland CL, MacRae CN et al.: The cognitive neuroscience of self-regulation. In: Baumeister RF, Vohs KD (eds.): The Handbook of Self-Regulation: Research, Theory, and Applications. Guilford Press, New York 2004: 62-83.

Basińska MA: Reumatoidalne zapalenie stawów. Obraz psychologiczny. Wydawnictwo Uniwersytetu Kazimierza Wielkiego, Bydgoszcz 2006.

Brzeziński J: Kształtowanie się mechanizmu kontroli emocjonalnej. Kwartalnik Pedagogiczny 1973; 18 (3): 99-108.

Brzeziński J: Kwestionariusz Kontroli Emocjonalnej (KKE). Pracownia Testów Psychologicznych, Warszawa 1980.

Cacioppo JT, Uchino BN, Crites SL et al.: Relationship between facial expressiveness and sympathetic activation in emotion: a critical review, with emphasis on modeling underlying mechanisms and individual differences. J Pers Soc Psychol 1992; 62: 110-128.

Critchley HD: Psychophysiology of neural, cognitive and affective integration: fMRI and autonomic indicants. Int J Psychophysiol 2009; 73: 88-94.

Doliński D: Emocje, poznanie i zachowanie. In: Strelau J (ed.): Psychologia. Podręcznik akademicki. Tom 2 - Psychologia ogólna. Gdańskie Wydawnictwo Psychologiczne, Gdańsk 2000a: 367-426.

Doliński D: Mechanizmy wzbudzania emocji. In: Strelau J (ed.): Psychologia. Podręcznik akademicki. Tom 2 - Psychologia ogólna Gdańskie Wydawnictwo Psychologiczne, Gdańsk 2000b: 320-343.

Eisenberg N, Fabes RA, Guthrie IK et al.: Dispositional emotionality and regulation: Their role in predicting quality of social functioning. J Pers Soc Psychol 2000; 78: 136-157.

Fedeli M: Temperamenty, charaktery, osobowości. Wydawnictwo WAM, Kraków 2004.

Feldner MT, Zvolensky MJ, Eifert GH et al.: Emotional avoidance: an experimental test of individual differences and response suppression using biological challenge. Behav Res Ther 2003; 41: 403-411.

Górska D, Soroko E: Poznawcze aspekty regulacji emocjonalnej. In: Kaliszewska K, Sakson-Obada O, Zielona-Jenek M et al. (eds.): Emocja - subiektywne doświadczenie czy zdarzenie interpersonalne? Bogunki Wydawnictwo Naukowe, Poznań 2004: 31-44.

Gross JJ: Emotion regulation: affective, cognitive, and social consequences. Psychophysiology 2002; 39: 281-291.

Gross JJ, John OP: Facets of emotional expressivity: three self-report factors and their correlates. Pers Individ Dif 1995; 19: 555-568.

Gross JJ, John OP: Individual differences in two emotion regulation processes: implications for affect, relationships, and well-being. J Pers Soc Psychol 2003; 85: 348-362.
Gross JJ, Thompson RA: Emotion regulation: conceptual foundations. In: Gross JJ (ed.): Handbook of Emotion Regulation. Guilford Press, New York 2007: 3-24.

Gyurak A, Goodkind MS, Madan A et al.: Do tests of executive functioning predict ability to downregulate emotions spontaneously and when instructed to suppress? Cogn Affect Behav Neurosci 2009; 9: 144-152.

Karrass J, Walden TA, Conture EG et al.: Relation of emotional reactivity and regulation to childhood stuttering. J Commun Disord 2006; 39: 402-423.

Kayser J, Tenke CE, Gil RB et al.: Stimulus- and response-locked neuronal generator patterns of auditory and visual word recognition memory in schizophrenia. Int J Psychophysiol 2009; 73: 186-206.

Krohne HW, Pieper M, Knoll N et al.: The cognitive regulation of emotions: the role of success versus failure experience and coping dispositions. Cogn Emot 2002; 16: 217-243.

Orzechowska A, Talarowska M, Wysokiński A et al.: Wybrane czynniki psychologiczne w łuszczycy i trądziku różowatym. Dermatol Klin 2009; 11: 17-20.

Pastuszak-Draxler A, Bętkowska-Korpała B, Gierowski JK: Predykcyjna rola strategii regulacji emocji negatywnych i pozytywnych dla symptomów depresji i lęku. Sztuka Leczenia 2016; 2: 55-65.

Pollatos O, Herbert BM, Matthias E et al.: Heart rate response after emotional picture presentation is modulated by interoceptive awareness. Int J Psychophysiol 2007; 63: 117-124.

Posner MI, Rothbart MK: Developing mechanisms of self-regulation. Dev Psychopathol 2000; 12: 427-441.

Rottenberg J, Gross JJ: When emotion goes wrong: realizing the promise of affective science. Clin Psychol (New York) 2003; 10: 227-232.

Shimamura AP: Toward a cognitive neuroscience of metacognition. Conscious Cogn 2000; 9: 313-323.

Tarkowski Z: A Systems Approach to the Psychosomatics of Stuttering. Nova Science Publishers, New York 2018.

Troyer AK, Moscovitch M, Winocur G: Clustering and switching as two components of verbal fluency: evidence from younger and older healthy adults. Neuropsychology 1997; 11: 138-146.

Vanryckeghem M, Brutten GJ, Uddin N et al.: A comparative investigation of the speech-associated coping responses reported by adults who do and do not stutter. J Fluency Disord 2004; 29: 237-250.

Worthman CM: Habits of the heart: life history and the developmental neuroendocrinology of emotion. Am J Hum Biol 2009; 21: 772-781. 